\title{
Heart failure is the strongest predictor of acute kidney injury in patients undergoing primary percutaneous coronary intervention for ST-elevation myocardial infarction
}

\author{
Jan Matějka ${ }^{1,2,4}$, Ivo Varvařovský ${ }^{1,2}$, Vladimír Rozsíval ${ }^{1,2}$, Aleš Herman ${ }^{1}$, Karel Bláha ${ }^{2,4}$, Jan Večeřa ${ }^{1,2,4}$, \\ Tomáš Lazarák ${ }^{1,2,4}$, Vojtěch Novotný1, 2, 4, Vladimíra Mužáková3 ${ }^{3}$, Petr Vojtíšek ${ }^{2,4}$ \\ ${ }^{1}$ Cardiology Centre AGEL, Pardubice, Czech Republic \\ 2Department of Cardiology, Regional Hospital Pardubice, Czech Republic \\ ${ }^{3}$ Department of Biological and Biochemical Sciences, Faculty of Chemical Technology, University of Pardubice, Czech Republic \\ ${ }^{4}$ Faculty of Health Studies, University of Pardubice, Czech Republic
}

\begin{abstract}
A b stract
Background: ST elevation myocardial infarction (STEMI) patients treated by primary percutaneous coronary intervention (PCI) are at higher risk of acute kidney injury (AKI) than patients undergoing $\mathrm{PCl}$ in stable clinical conditions. This fact suggests that mechanisms other than contrast nephrotoxicity are involved.

Aim: To evaluate the incidence, risk factors, and consequences of AKI in patients undergoing primary PCI for STEMI in current daily practice.

Methods: Analysis of all consecutive patients who underwent primary PCl over a one-year period. AKI was defined as an increase in serum creatinine $\geq 50 \%$ or $26.5 \mu \mathrm{mol} / \mathrm{L}$ (AKIN criteria) from the baseline within $48 \mathrm{~h}$.

Results: A total of 202 patients were included. AKI occurred in 25 (12.4\%) subjects. Baseline characteristics and in-hospital complications of the patients with and without AKI did not differ significantly except for age (69 \pm 13 vs. $62 \pm 12 ; p=0.003)$, female gender (48.0\% vs. $26.6 \% ; p=0.035)$, hypertension ( $88.0 \%$ vs. $62.7 \% ; p=0.013)$, left ventricular ejection fraction $(40 \% \pm 12 \%$ vs. $49 \% \pm 14 \% ; p=0.002)$, cardiogenic shock (44.0\% vs. $5.1 \% ; p<0.0001)$, use of intravenous diuretics $(76.0 \%$ vs. $26.0 \% ; p<0.0001)$, ventricular arrhythmias $(24.0 \%$ vs. $3.4 \% ; p=0.001)$, and in-hospital mortality $(24.0 \%$ vs. $3.4 \%$; $\mathrm{p}=0.001$ ). In multivariate analysis heart failure remained the only independent correlate of AKI.

Conclusions: AKI was an frequent and serious complication of STEMI in patients treated by primary PCI. Heart failure was the strongest predictor of AKI. Other risk factors including contrast medium volume, baseline renal function, diabetes, and age failed to predict AKI.
\end{abstract}

Key words: acute kidney injury, contrast-induced acute kidney injury, ST elevation, myocardial infarction, primary percutaneous coronary intervention, complications

Kardiol Pol 2016; 74, 1: 18-24

\section{INTRODUCTION}

Primary percutaneous coronary intervention $(\mathrm{PCl})$ is currently the most effective reperfusion strategy in ST-elevation acute myocardial infarction (STEMI). STEMI represents a major medical and socioeconomic problem, and our country has a unique system of care for STEMI patients. 92\% of all hospitalised STEMI patients are treated by primary $\mathrm{PCI}$ due to a network of cathlabs and emergency medical services [1]. However, data regarding renal complications of primary $\mathrm{PCI}$ are lacking. 
Acute renal function impairment associated with radiologic procedures, known as contrast-induced acute kidney injury (Cl-AKI), is strongly associated with a higher rate of morbidity and in-hospital mortality, and diminished long-term survival [2]. Patients with acute myocardial infarction undergoing primary $\mathrm{PCl}$ are at increased risk of acute kidney injury (AKI) [3, 4]. This fact suggests that mechanisms other than direct contrast nephrotoxicity are involved in AKI in this clinical setting.

This report describes the incidence, risk factors, and consequences of $\mathrm{AKI}$ in patients undergoing primary $\mathrm{PCl}$ for STEMI in current daily practice.

\section{METHODS}

We performed a retrospective analysis of all consecutive patients who underwent primary PCI for STEMI at our institution from 1.01.2010 to 31.12.2010. Patients on long-term renal replacement therapy were excluded.

Hospitalisation mortality data was gathered from the National Registry of Cardiovascular Interventions (NRKI). NRKI data is matched with the national death registry periodically.

Estimated glomerular filtration rate (eGFR) was calculated according to MDRD equation [5].

AKI was defined as an increase in serum creatinine $(\mathrm{sCr}) \geq 50 \%$ or $26.5 \mu \mathrm{mol} / \mathrm{L}$ (AKIN criteria) from the baseline value within a 48-h period [6].

Maximum acceptable contrast dose (MACD) was defined as follows: MACD $[\mathrm{mL}]=5 \times$ body weight $[\mathrm{kg}] / \mathrm{sCr}[\mathrm{mg} / \mathrm{dL}]$ [7]. MACD ratio was defined as follows: $M A C D$ ratio $=$ contrast volume administered [mL] / MACD [mL].

Contrast induced nephropathy $(\mathrm{CIN})$ risk score was calculated according to eight clinical and procedural variables [8].

\section{Statistical analysis}

Continuous data are expressed as mean \pm standard deviation (age, sCr, eGFR, left ventricular ejection fraction [LVEF], contrast volume, fluoroscopy time), interquartile range (age, eGFR), or median (age, fluoroscopy time). Categorical data are presented as absolute values and/or percentages. To compare continuous parameters Student unpaired t test was used, and between-group differences in dichotomous data were analysed with the use of Fisher exact test using NCSS2000 software (Dr Jerry L. Hintze, Kaysville, Utah, USA). A multiple logistic regression model was developed to identify independent predictors of AKI. Age, gender, LVEF, use of diuretics, and presence of heart failure (HF) (Killip class II, III, or IV) were selected among variables significant in univariate analysis.

Principal component analysis (PCA) was applied to a set of variables (Killip class, vital status, CIN risk score, MACD ratio, heart rate, left main disease, number of diseased vessels, age, gender, ejection fraction, and presence of hypertension) to discover coherent subsets of variables that are relatively independent of one another. Analyses of correlation matrix were carried out using the software STATISTICA (Statsoft, Tulsa, OK, USA).

\section{RESULTS}

A total of 202 consecutive patients who underwent primary $\mathrm{PCI}$ for STEMI were included in our analysis. Regarding nephroprotective measures, apart from the oral fluid intake, all patients received normal saline infusion during primary $\mathrm{PCl}$, and the infusion rate was adjusted or infusion was stopped according to the clinical status of the patients. One hundred (49.5\%) patients received continuous normal saline infusion during coronary care unit hospitalisation. All patients were administered low-osmolar non-ionic contrast medium iomeprol 300. Demographic and baseline characteristics of the patients are summarised in Table 1.

AKI according to AKIN criteria occurred in 25 (12.4\%) subjects. Two (1.0\%) patients in cardiogenic shock required continuous veno-venous haemodialysis. The overall in-hospital mortality rate was 5.9\% (12 patients). The MACD was exceeded in six $(3.0 \%)$ patients.

Table 2 shows clinical, procedural characteristics and in-hospital complications of the study patients who developed $\mathrm{AKI}$ and those who did not.

In multivariate analysis, the only variable that remained an independent correlate of AKI was HF (Killip class II, III or IV) (Table 3).

Table 1. Demographic and baseline data of patients who underwent primary percutaneous coronary intervention $(n=202)$

\begin{tabular}{|lc|}
\hline Age [years] (IQR) & $63 \pm 12(56-73)$ \\
Female sex & $59(29.2 \%)$ \\
Hypertension & $132(65.3 \%)$ \\
Diabetes mellitus & $67(33.2 \%)$ \\
History of chronic heart failure & $8(4 \%)$ \\
Smokers & $88(43.6 \%)$ \\
Hyperlipidaemia & $147(72.8 \%)$ \\
Body mass index $\left[\mathrm{kg} / \mathrm{m}^{2}\right]$ & $27.6 \pm 3.9$ \\
Killip class: & \\
I & $147(72.8 \%)$ \\
II & $29(14.4 \%)$ \\
III & $6(2.9 \%)$ \\
IV & $20(9.9 \%)$ \\
Serum creatinine $\left[\mu \mathrm{mol}^{2} \mathrm{~L}\right]$ & $105 \pm 27$ \\
eGFR [mL/min/1.73 m²] (IQR) & $65.9 \pm 19.4(51.7-79.3)$ \\
Contrast volume administered $[\mathrm{mL}]$ & $173 \pm 42$
\end{tabular}

Plus-minus values are means \pm standard deviation; percentages are presented in parentheses; eGFR - estimated glomerular filtration rate; Killip class: I - no signs of heart failure; II — rales or gallop; III - pulmonary oedema; IV — cardiogenic shock; IQR — interquartile range 
Table 2. Baseline clinical, procedural characteristics and in-hospital complications of the study patients who developed acute kidney injury (AKI) and those who did not

\begin{tabular}{|c|c|c|c|}
\hline & AKI $(n=25)$ & No AKI $(n=177)$ & $\mathbf{P}$ \\
\hline Age [years] & $69 \pm 13 ; 64 \S$ & $62 \pm 12 ; 62 \S$ & $0.003 \dagger$ \\
\hline Female gender & $12(48.0 \%)$ & $47(26.6 \%)$ & $0.035 \ddagger$ \\
\hline Hypertension & $22(88.0 \%)$ & $111(62.7 \%)$ & $0.013 \ddagger$ \\
\hline Diabetes mellitus & $10(40.0 \%)$ & $58(32.8 \%)$ & $0.502 \ddagger$ \\
\hline Chronic heart failure & $2(8.0 \%)$ & $6(3.4 \%)$ & $0.259 \ddagger$ \\
\hline Dyslipidaemia & $15(60.0 \%)$ & $132(74.6 \%)$ & $0.150 \ddagger$ \\
\hline Smokers & $8(32.0 \%)$ & $80(45.2 \%)$ & $0.282 \ddagger$ \\
\hline Serum creatinine $[\mu \mathrm{mol} / \mathrm{L}]$ & $110 \pm 39$ & $104 \pm 25$ & $0.549 \dagger$ \\
\hline $\mathrm{eGFR}\left[\mathrm{mL} / \mathrm{min} / 1.73 \mathrm{~m}^{2}\right]$ & $62.1 \pm 25.8$ & $66.5 \pm 18.4$ & $0.493 \dagger$ \\
\hline LVEF [\%] & $40 \pm 12$ & $49 \pm 14$ & $0.002 \dagger$ \\
\hline \multicolumn{4}{|l|}{ Killip class: } \\
\hline I & $5(20.0 \%)$ & $142(80.2 \%)$ & $<0.0001 \neq$ \\
\hline$\|$ & $7(28.0 \%)$ & $22(12.4 \%)$ & $0.061 \neq$ \\
\hline III & $2(8.0 \%)$ & $4(2.3 \%)$ & $0.162 \ddagger$ \\
\hline IV & $11(44.0 \%)$ & $9(5.1 \%)$ & $<0.0001 \neq$ \\
\hline Contrast volume [mL] & $186 \pm 45$ & $172 \pm 40$ & $0.429 \dagger$ \\
\hline Fluoroscopy time [min] & $9.9 \pm 6.7$ & $8.0 \pm 4.5$ & $0.199 \dagger$ \\
\hline Fluid intake $[\mathrm{mL}]^{*}$ & $1031 \pm 471$ & $1024 \pm 458$ & $0.740 \dagger$ \\
\hline Diuresis $[\mathrm{mL}]^{*}$ & $628 \pm 555$ & $695 \pm 628$ & $0.659 \dagger$ \\
\hline Use of nephrotoxic drugs & $1(4.0 \%)$ & $5(2.8 \%)$ & 0.552 \\
\hline Use of IV diuretics & $19(76.0 \%)$ & $46(26.0 \%)$ & $<0.0001 \neq$ \\
\hline Transradial approach & $12(48.0 \%)$ & $79(44.6 \%)$ & $0.831 \ddagger$ \\
\hline \multicolumn{4}{|l|}{ Diseased vessels: } \\
\hline One-vessel & $4(16.0 \%)$ & 75 (42.4\%) & $0,015 \ddagger$ \\
\hline Two-vessel & $8(32.0 \%)$ & $66(37.3 \%)$ & $0,664 \ddagger$ \\
\hline Three-vessel & $9(36.0 \%)$ & $31(17.5 \%)$ & $0.056 \ddagger$ \\
\hline Left main & $4(16.0 \%)$ & $5(2.8 \%)$ & $0.015 \ddagger$ \\
\hline IABP & $3(12.0 \%)$ & $1(0.6 \%)$ & $0.006 \ddagger$ \\
\hline In-hospital death & $6(24.0 \%)$ & $6(3.4 \%)$ & $0.001 \ddagger$ \\
\hline VT/NF & $6(24.0 \%)$ & $6(3.4 \%)$ & $0.001 \neq$ \\
\hline In-hospital death and VT/VF & $3(12.0 \%)$ & $2(1.1 \%)$ & $0.014 \ddagger$ \\
\hline Atrial fibrillation & $3(12.0 \%)$ & $5(2.8 \%)$ & $0.062 \ddagger$ \\
\hline High-degree conduction disturbances & $2(8.0 \%)$ & $5(2.8 \%)$ & $0.209 \ddagger$ \\
\hline Stroke & $1(4.0 \%)$ & $0(0.0 \%)$ & $0.124 \ddagger$ \\
\hline Mechanical complications & $1(4.0 \%)$ & $2(1.1 \%)$ & $0.329 \ddagger$ \\
\hline TIMI major bleeding & $1(4.0 \%)$ & $0(0.0 \%)$ & $0.124 \ddagger$ \\
\hline TIMI minor bleeding & $1(4.0 \%)$ & $2(1.1 \%)$ & $0.329 \neq$ \\
\hline
\end{tabular}

Plus-minus values are means \pm standard deviation; percentages are presented in parentheses; $\S$ Median; $\ddagger$ Fisher exact test was used; † Student unpaired t test was used; * Fluid balance 0-6 h after hospital admission; eGFR — estimated glomerular filtration rate; Killip class: I — no signs of heart failure; II — rales or gallop; III — pulmonary oedema; IV — cardiogenic shock; LVEF — left ventricular ejection fraction; IABP — intra-aortic balloon counterpulsation; VTNF — ventricular tachycardia and/or ventricular fibrillation

Heart failure (Killip class II, III or IV) predicted AKI with $80 \%$ sensitivity, $80 \%$ specificity, 36\% positive predictive value (PPV), and $97 \%$ negative predictive value (NPV). Cardiogenic shock (Killip class IV) predicted AKI with 93\% NPV and 56\% PPV.
Figure 1 shows principal components analysis and factor analysis applied to a set of the most important variables related to $\mathrm{AKI}$. Killip class and CIN risk score co-vary strongly with AKI in a positive sense. Male gender, LVEF, and blood 
Table 3. Multivariate analysis of predictors of acute kidney injury

\begin{tabular}{llc|} 
& $\begin{array}{c}\text { Adjusted RR; } \\
95 \% \text { Cl }\end{array}$ & P \\
\hline Age & $1.03 ; 0.99-1.08$ & 0.182 \\
Female gender & $1.70 ; 0.63-4.56$ & 0.295 \\
LVEF & $1.01 ; 0.97-1.06$ & 0.529 \\
Diuretics & $0.43 ; 0.13-1.44$ & 0.169 \\
Heart failure (Killip class II, & $3.35 ; 1.64-6.83$ & 0.001 \\
III or IV) & & \\
\hline
\end{tabular}

Multiple logistic regression analysis; Diuretics, use of diuretics within $48 \mathrm{~h}$ after primary percutaneous coronary intervention; RR - relative risk; rest abbreviations as in Table 2

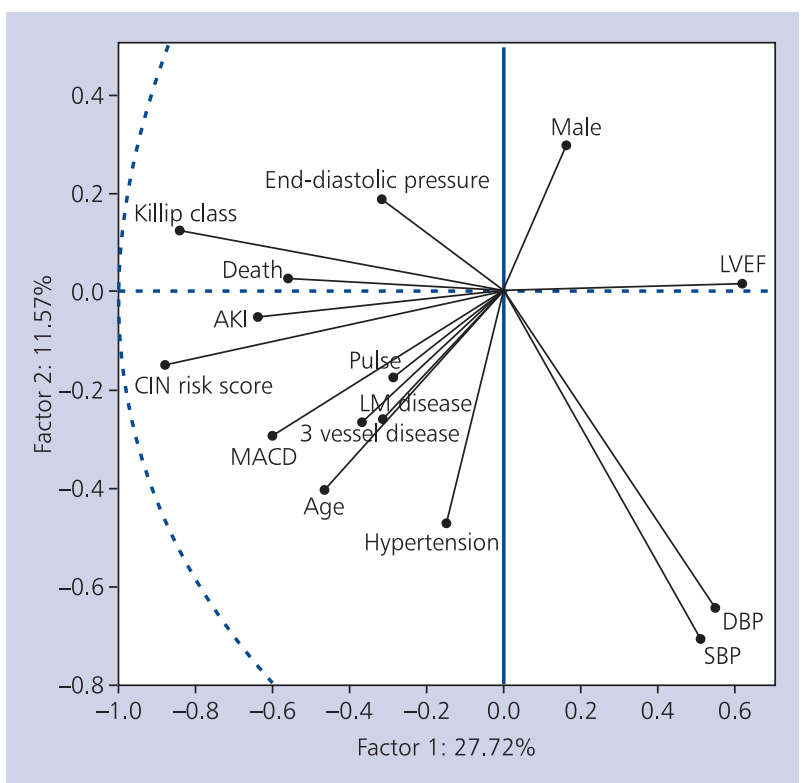

Figure 1. Principal components analysis and factor analysis. Variables with a high degree of systemic variation lie far away from the origin. Variables of little importance lie near the origin. It is mandatory to consider proportions of the variance along each component, Factor 1 is nearly three times as important as Factor 2. Variables close to each other co-vary strongly, proportionally to the degree of distance from the origin. If the variables lie on the same side of the origin, they co-vary in a positive sense; if they lie on the opposite side of the origin along a straight line, they are negatively correlated. Variables which are at 90 degrees to each other through the origin are independent; AKI — acute kidney injury; CIN — contrast induced nephropathy; LM disease - left main coronary artery stenosis $\geq 50 \%$; MACD - maximum allowable contrast dose ratio; LVEF — left ventricular ejection fraction; SBP — systolic blood pressure; DBP — diastolic blood pressure

pressure co-vary with $\mathrm{AKI}$ in a negative sense. Figure 2 shows that $\mathrm{AKI}$ occurrence increases in every consecutive Killip class category.

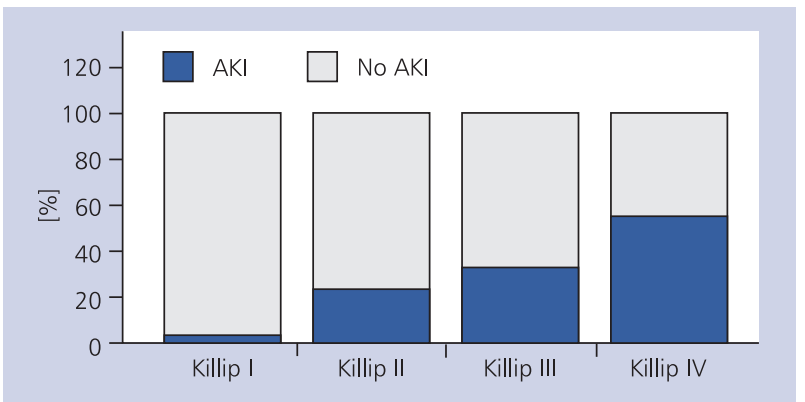

Figure 2. Acute kidney injury development in different Killip classes; AKI — proportion of patients who developed acute kidney injury; No AKI — proportion of patients who did not develop acute kidney injury; Killip class: I - no signs of heart failure; II — rales or gallop; III — pulmonary oedema; IV - cardiogenic shock

\section{DISCUSSION}

The results of our study suggest that AKI in STEMI patients treated with primary $\mathrm{PCI}$ represents a relatively frequent adverse event and affects approximately $12 \%$ of patients. AKI occurrence was associated with increased in-hospital mortality (24\% vs. $3.4 \% ; p=0.001)$ and morbidity.

The major finding of this study is that the only independent predictor of $\mathrm{AKI}$ in the setting of STEMI treated by primary $\mathrm{PCl}$ was HF.

Heart failure patients were at four times higher risk of AKI than those without HF. Although the PPV of HF for AKI development was low (36\%), the NPV of $97 \%$ could bring us valuable and fast clinical information. In the absence of rales, third heart sound, pulmonary oedema, or shock the risk of AKI in STEMI patients does not exceed 3\%, and therefore particular nephroprotective measures are probably not needed. Cardiogenic shock occurs in approximately $7-10 \%$ of all STEMI patients. Shock patients represented $9.9 \%$ of our sample. Cardiogenic shock predicted AKI with 56\% PPV. The fact that more than half of cardiogenic shock patients developed AKI was conformant with previously published data [9].

On the other hand, other established risk factors used commonly in patients undergoing elective coronary angiography and/or PCI failed to predict AKI in our analysis. Although patients who developed AKI were older than patients without AKI development, age did not remain a significant predictor of $\mathrm{AKI}$ in multivariate analysis. The proportion of diabetics and patients without diabetes did not differ significantly between $\mathrm{AKI}$ and non-AKI groups. Baseline renal function was within normal or mild reduction range and did not differ between the above-mentioned groups. The proportion of patients with history of chronic HF was low and did not differ between AKI and non-AKI groups. Use of nephrotoxic drugs did not influence AKI development. Use of intravenous diuretics was higher in the AKI group. It correlated strongly with $\mathrm{HF}$ and did not remain a significant predictor of $\mathrm{AKI}$ in multivariate analysis. 
STEMI patients treated by primary $\mathrm{PCI}$ represent a population at higher risk for $\mathrm{AKI}$ than those undergoing elective coronary angiography and/or PCI. Renal hypoperfusion caused by HF or prolonged hypotension, larger volume of contrast media, bleeding, and atheroembolic events during catheterisation are the most cited conditions that contribute to renal injury $[3,9,10]$.

Our data suggest that HF is the predominant contributor to $\mathrm{AKI}$ in this clinical setting. AKI CO-varied strongly with HF (Fig. 1). Contrast media consumption was relatively low. Transradial approach in one half of the patients led to a low incidence of bleeding and possible lower risk of atheroembolic events. However, a direct causal link between AKI and its particular risk factors cannot be confirmed by our data.

Acute myocardial infarction itself leads to kidney injury even when no contrast media is administered. Koreny et al. [11] analysed all consecutive patients admitted for acute myocardial infarction with cardiogenic shock in a single centre from 1993 to 2000. AKI developed in 33\% of patients within 24 h. Coronary angiography was performed only in 34\% patients and had no effect on kidney injury incidence [11]. In the SHOCK trial, AKI was even more frequent in patients treated with initial medical therapy (with no contrast administration) than in those treated with early revascularisation (24\% vs. $13 \%$ ) [12].

AKI in acute STEMI is considered to be one of the subtypes of type 1 cardiorenal syndrome (acute cardiorenal syndrome) and represents a powerful and independent predictor of in-hospital and one-year mortality [13]. As yet we cannot differentiate the effect of contrast media administration from different mechanisms involved in AKI development in STEMI patients with HF including haemodynamic abnormalities (hypoperfusion with decreased renal preload, increased central venous pressure with increased renal afterload), sympathetic hyperactivity, renin-angiotensin-aldosterone system activation, adenosine release, and oxidative stress [14]. The universal term AKI may be more appropriate than $\mathrm{Cl}-\mathrm{AKI}$ in this clinical setting. Novel markers of renal dysfunction might bring additional information about the mechanisms and prognosis of kidney injury and provide its earlier detection [15-17].

In accordance with the findings of Wi et al. [18], Mehran $\mathrm{CIN}$ risk score correlated strongly with $\mathrm{AKI}$ in our analysis (Fig. 1). Of the eight CIN risk score variables, the three strongest ones are related to HF (hypotension, intra-aortic balloon counterpulsation, NYHA class III and IV, or pulmonary oedema).

There is a significant difference between the analysed groups with respect to ventricular tachycardia and/or ventricular fibrillation. This subgroup of patients is very small and heterogeneous including a spectrum of patients from primary ventricular fibrillation at the coronary care unit without further sequelae to patients with ventricular arrhythmias in cardiogenic shock terminal phase. Interpretation of the data is beyond the scope of this paper.
Nevertheless, the Killip classification remains a very simple and useful tool for physicians. It can bring us valuable information regarding AKI risk (Fig. 2).

Four potential preventive strategies against AKI have been evaluated in STEMI patients undergoing primary $\mathrm{PCl}$; however, the data are too sparse to make a clinical recommendation $[4,19]$. This paper reflects our daily practice. We focused on adequate hydration and use of low volume of contrast. Fluid balance within $6 \mathrm{~h}$ after primary $\mathrm{PCl}$ did not differ between both of the above-mentioned groups. Fluid intake within $6 \mathrm{~h}$ post $\mathrm{PCl}$ exceeded $960 \mathrm{~mL}$, the threshold for high risk of AKI according to Maioli et al. [19].

The volume of low-osmolar contrast agent administered $(173 \pm 42 \mathrm{~mL})$ was lower than in older relevant trials or similar to recent trials $[3,9,10]$. MACD was exceeded in $3 \%$ of patients only. This fact suggests that the technique of primary $\mathrm{PCl}$ has evolved and experienced operators are more capable of achieving successful procedure results with a lower amount of contrast agent. Patients who developed AKI were not administered significantly higher doses of contrast media than patients without AKI.

According to the findings of our analysis, we should target the predominant risk factor, HF. In other words, we should use all necessary measures to assure the optimal haemodynamic status of our STEMI patient. Paradoxically, early revascularisation with contrast media administration is one of those measures.

\section{Limitations of the study}

The results of this paper should be regarded within the setting of certain limitations. Our analysis reflects a single-centre experience, and the population studied is relatively small. Follow-up was limited to in-hospital morbidity and mortality. However, mortality data was cross-checked with the national death registry. Conclusions should be drawn carefully. A larger sample size could increase the power of statistical analysis and allow the discrimination of other independent predictors of AKI.

\section{CONCLUSIONS}

AKI was found to be a frequent complication of STEMI in patients treated by primary $\mathrm{PCl}$ and was associated with increased in-hospital morbidity and mortality. Our data suggests that $\mathrm{HF}$ is the strongest predictor of $\mathrm{AKI}$ in this clinical setting. Other risks factors used commonly in patients undergoing elective coronary angiography and/or $\mathrm{PCl}$, including contrast medium volume, baseline renal function, diabetes, and age, failed to predict AKI.

\section{Conflict of interest: none declared}

\section{References}

1. Widimsky P, Wijns W, Fajadet J et al. European Association for Percutaneous Cardiovascular Interventions. Reperfusion therapy for ST elevation acute myocardial infarction in Europe: descrip- 
tion of the current situation in 30 countries. Eur Heart J, 2010; 31: 943-957. doi: 10.1093/eurheartj/ehp492.

2. McCullough PA. Contrast-induced acute kidney injury. J Am Coll Cardiol, 2008; 51: 1419-1428. Review. Erratum in: J Am Coll Cardiol, 2008; 51: 2197. doi: 10.1016/j.jacc.2007.12.035.

3. Marenzi G, Lauri G, Assanelli E et al. Contrast-induced nephropathy in patients undergoing primary angioplasty for acute myocardial infarction. J Am Coll Cardiol, 2004; 44: 1780-1785.

4. Busch SV, Jensen SE, Rosenberg J et al. Prevention of contrast-induced nephropathy in STEMI patients undergoing primary percutaneous coronary intervention: a systematic review. Prevention of contrast-induced nephropathy in STEMI patients undergoing primary percutaneous coronary intervention: a systematic review. J Interv Cardiol, 2013; 26: 97-105. doi: 10.1111/joic.12007.

5. Levey AS, Bosch JP, Lewis JB et al. A more accurate method to estimate glomerular filtration rate from serum creatinine: a new prediction equation. Modification of Diet in Renal Disease Study Group. Ann Intern Med, 130: 461-470.

6. KDIGO Clinical Practice Guideline for Acute Kidney Injury. Kidney International Supplements, 2012; 2: 19-36.

7. Brown JR, Robb JF, Block CA et al. Does safe dosing of iodinated contrast prevent contrast-induced acute kidney injury? Circ Cardiovasc Interv, 2010; 3: 346-350. doi: 10.1161/CIRCINTERVENTIONS.109.910638.

8. Mehran R, Aymong ED, Nikolsky E et al. A simple risk score for prediction of contrast-induced nephropathy after percutaneous coronary intervention: development and initial validation. J Am Coll Cardiol, 2004; 44: 1393-1399.

9. Marenzi G, Assanelli E, Campodonico J et al. Acute kidney injury in ST-segment elevation acute myocardial infarction complicated by cardiogenic shock at admission. Crit Care Med, 2010; 38: 438-444. doi: 10.1097/CCM.0b013e3181b9eb3b.

10. Thiele H, Hildebrand L, Schirdewahn C et al. Impact of high-dose $\mathrm{N}$-acetylcysteine versus placebo on contrast-induced nephropathy and myocardial reperfusion injury in unselected patients with ST-segment elevation myocardial infarction undergoing primary percutaneous coronary intervention. The LIPSIA-N-ACC
Trial. J Am Coll Cardiol, 2010; 55: 2201-2209. doi: 10.1016/j. jacc.2009.08.091.

11. Koreny M, Karth GD, Geppert A et al. Prognosis of patients who develop acute renal failure during the first 24 hours of cardiogenic shock after myocardial infarction. Am J Med, 2002; 112: 115-119.

12. Hochman JS, Sleeper LA, Webb JG et al. Early revascularization in acute myocardial infarction complicated by cardiogenic shock. SHOCK Investigators. Should We Emergently Revascularize Occluded Coronaries for Cardiogenic Shock. N Engl J Med, 1999; 341: 625-634.

13. Ronco C, Haapio M, House AA et al. Cardiorenal syndrome. J Am Coll Cardiol, 2008; 52: 1527-1539. doi: 10.1016/j. jacc.2008.07.051.

14. Metra M, Cotter G, Gheorghiade M et al. The role of the kidney in heart failure. Eur Heart J, 2012; 33: 2135-2142. doi: 10.1093/eurheartj/ehs205.

15. Briguori C, Visconti G, Rivera NV et al. Cystatin C and contrast-induced acute kidney injury. Circulation, 2010; 121: 2117-2122. doi: 10.1161/CIRCULATIONAHA.109.919639.

16. Malyszko J, Bachorzewska-Gajewska H, Poniatowski B et al. Urinary and serum biomarkers after cardiac catheterization in diabetic patients with stable angina and without severe chronic kidney disease. Ren Fail, 2009; 31: 910-919. doi: 10.3109/08860220903216113.

17. Karabulut A, Sahin I, Avcı II et al. Impact of serum alkaline phosphatase level in the pathophysiologic mechanism of contrast induced nephropathy. Kardiol Pol, 2014; 72: 977-982. doi: 10.5603/KP.a2014.0072.

18. Wi J, Ko YG, Shin DH et al. Prediction of contrast-induced nephropathy with persistent renal dysfunction and adverse long-term outcomes in patients with acute myocardial infarction using the mehran risk score. Clin Cardiol, 2013; 36: 46-53. doi: $10.1002 /$ clc. 22060 .

19. Maioli M, Toso A, Leoncini $\mathrm{M}$ et al. Effects of hydration in contrast-induced acute kidney injury after primary angioplasty: a randomized, controlled trial. Circ Cardiovasc Interv, 2011; 4: 456-462. doi: 10.1161/CIRCINTERVENTIONS.111.961391.

Cite this article as: Matějka J, Varvařovský I, Rozsíval V et al. Heart failure is the strongest predictor of acute kidney injury in patients undergoing primary percutaneous coronary intervention for ST-elevation myocardial infarction. Kardiol Pol, 2016; 74: 18-24. doi: 10.5603/KP.a2015.0115. 


\title{
Niewydolność serca jest najsilniejszym czynnikiem predykcyjnym ostrego uszkodzenia nerek u chorych poddanych pierwotnej przezskórnej interwencji wieńcowej z powodu zawału serca $\mathrm{z}$ uniesieniem odcinka ST
}

\author{
Jan Matějka ${ }^{1,2,4}$, Ivo Varvařovský1, ${ }^{1,}$, Vladimír Rozsíval ${ }^{1,2}$, Aleš Herman ${ }^{1}$, Karel Bláha ${ }^{2,4}$, Jan Večeřa ${ }^{1,2,4}$, \\ Tomáš Lazarák ${ }^{1,2,4}$, Vojtěch Novotný ${ }^{1,2,4}$, Vladimíra Mužáková3 ${ }^{3}$, Petr Vojtíšek ${ }^{2,4}$ \\ ${ }^{1}$ Cardiology Centre AGEL, Pardubice, Czechy \\ 2Department of Cardiology, Regional Hospital Pardubice, Czechy \\ ${ }^{3}$ Department of Biological and Biochemical Sciences, Faculty of Chemical Technology, University of Pardubice, Czechy \\ ${ }^{4}$ Faculty of Health Studies, University of Pardubice, Czechy
}

\section{Streszczenie}

Wstęp: Chorzy z zawałem serca z uniesieniem odcinka ST (STEMI) leczeni za pomocą pierwotnej przezskórnej interwencji wieńcowej (PCI) są obciążeni zwiększonym ryzykiem ostrego uszkodzenia nerek (AKI) niż pacjenci poddani PCI w stabilnym stanie klinicznym. To sugeruje istnienie innych mechanizmów prowadzących do AKI niż nefrotoksyczne działanie środka kontrastowego.

Cel: Badanie przeprowadzono w celu oceny częstości występowania, czynników ryzyka i następstw AKI u chorych poddanych pierwotnej $\mathrm{PCI}$ z powodu STEMI w warunkach codziennej praktyki.

Metody: Przeanalizowano dane kolejnych pacjentów poddanych pierwotnej PCI w okresie obejmującym ponad rok. Ostre uszkodzenie nerek definiowano jako zwiększenie kreatyniny w surowicy o $\geq 50 \%$ lub 26,5 $\mu \mathrm{mol} / \mathrm{l}$ (kryteria AKIN) w stosunku do wartości wyjściowych w ciągu 48 godzin.

Wyniki: Do badania włączono 202 chorych. Ostre uszkodzenie nerek stwierdzono u 25 (12,4\%) osób. Charakterystyka wyjściowa i powikłania wewnątrzszpitalne nie różniły się istotnie między pacjentami, u których nastąpiło AKI, a osobami bez ostrego uszkodzenia nerek, poza następującymi zmiennymi: wiek (69 \pm 13 vs. $62 \pm 12$; p = 0,003), płeć żeńska (48,0\% vs. $26,6 \%$; $p=0,035)$, nadciśnienie tętnicze $(88,0 \%$ vs. $62,7 \%$; $p=0,013)$, frakcja wyrzutowa lewej komory $(40 \% \pm 12 \%$ vs. $49 \% \pm 14 \% ; p=0,002)$, wstrząs kardiogenny $(44,0 \%$ vs. 5,1\%; $p<0,0001)$, stosowanie dożylnych diuretyków $(76,0 \%$ vs. $26,0 \%$; $p<0,0001)$, komorowe zaburzenia rytmu (24,0\% vs. 3,4\%; $p=0,001)$ oraz śmiertelność wewnątrzszpitalna $(24,0 \%$ vs. $3,4 \% ; p=0,001)$. W analizie wielozmiennej niewydolność serca pozostała jedynym niezależnym korelatem AKI. Wnioski: Ostre uszkodzenie nerek było częstym i poważnym powikłaniem STEMI u chorych poddanych pierwotnej PCI. Niewydolność serca była najsilniejszym czynnikiem predykcyjnym AKI. Inne czynniki ryzyka, w tym objętość podanego środka kontrastowego, wyjściowa czynność nerek, cukrzyca i wiek, nie miały wartości prognostycznej w ocenie ryzyka AKI. Słowa kluczowe: ostre uszkodzenie nerek, pokontrastowe ostre uszkodzenie nerek, zawał serca z uniesieniem odcinka ST, pierwotna przezskórna interwencja wieńcowa, powikłania 